\title{
Urinary-Based Markers for Bladder Cancer Detection
}

\author{
Tilman Todenhöfer, ${ }^{凶 1,2}$ Michele Lodde, ${ }^{3}$ Kim van Kessel, ${ }^{4}$ Renate Pichler, ${ }^{5}$ Antonia Vlahou, ${ }^{6}$ Yair Lotan ${ }^{7}$ \\ ${ }^{1}$ Studienpraxis Urology, Clinical Trial Unit, Germany, ${ }^{2}$ Medical School, University of Tuebingen, Germany, ${ }^{3}$ Centre Hospitalier Universitaire de Québec Research Centre, \\ Université Laval, Québec, Canada, ${ }^{4}$ Erasmus MC Cancer Institute, Rotterdam, The Netherlands, ${ }^{5}$ Department of Urology, Medical University Innsbruck, Austria, \\ ${ }^{6}$ Biomedical Research Foundation, Academy of Athens, Greece, ${ }^{7}$ Department of Urology, University of Texas Southwestern Medical Center, Dallas, United States
}

\begin{abstract}
Background The use of urine markers for diagnosis and surveillance has been a topic of broad interest and ongoing controversies in the management of patients with bladder cancer. There has been a constant quest for markers that demonstrate clinical utility.

Aim In the framework of the International Consultation on Urological Diseases 2019 on Molecular Biomarkers in Urologic Oncology, a comprehensive review of literature on urinary biomarkers for bladder cancer has been performed.

Results Currently available urinary markers include protein-based markers, RNA-based markers, and DNA-based markers. The introduction of high-throughput analysis technologies provides the opportunity to assess multiple parameters within a short period of time, which is of interest for RNA-based, DNA-based, and protein-based marker systems. A comprehensive analysis of molecular alterations in urine samples of bladder cancer patients may be of interest not only for diagnosis and surveillance but also for non-invasive longitudinal assessment of molecular, potentially therapy-relevant, alterations. However, most systems lack prospective validation within well-designed trials and have not been broadly implemented in daily clinical practice.

Conclusions Because of limited data from prospective trials, the routine use of any urine marker except cytology is not considered as standard of care in international guidelines. There is an urgent need for prospective trials of urine markers to answer specific clinical questions.
\end{abstract}

\section{Introduction}

A diagnosis of bladder cancer (BC) is routinely made by cystoscopy followed by biopsy of suspicious lesions $[1,2]$. Cystoscopy represents the most important component of surveillance of BC. However, as white light cystoscopy may miss tumors and may be associated with discomfort for the patient, there has been a constant interest in the discovery of urine markers for use in diagnosis and surveillance of $\mathrm{BC}$ patients [3,4]. A marker with reasonable performance may be of interest in different clinical scenarios. These scenarios include the use of urine markers for patients with symptoms suggestive of BC (such as hematuria) and urine marker based surveillance (eg, with adaptation of cystoscopy intervals according to urine marker results) [5]. So far, the majority of studies performed in this field have shown that an increased sensitivity of non-cytology urine markers, compared with cytology, is often associated with limited specificity and that various factors (eg, infection and hematuria) frequently encountered in the patient population that is of interest for these markers may limit the diagnostic accuracy. A decreased specificity is also the

\section{Key Words}

Urine, biomarkers, surveillance, screening, hematuria, urothelial carcinoma

\section{Competing Interests}

Dr Lotan reports grants from MdxHealth, grants from Pacific Edge, grants from Cepheid, grants from Decipher Biosciences, personal fees from Nucleix, personal fees from Photocure, personal fees from Merck, personal fees from AstraZeneca, personal fees from Fergene, during the conduct of the study. The remaining authors report no competing interests

\section{Article Information}

Received on July 7, 2020

Accepted on July 29, 2020

Soc Int Urol J. 2020;1(1):49-61 


\section{Abbreviations

$\begin{array}{ll}\text { AUA } & \text { American Urological Association } \\ \text { BC } & \text { bladder cancer } \\ \text { BCG } & \text { Bacillus Calmette-Guérin } \\ \text { EAU } & \text { European Association of Urology } \\ \text { FISH } & \text { fluorescence in situ hybridization } \\ \text { HGBC } & \text { high-grade bladder cancer } \\ \text { miRNA } & \text { microRNA } \\ \text { NMIBC } & \text { non-muscle invasive bladder cancer } \\ \text { NMP22 } & \text { nuclear matrix protein 22 } \\ \text { TERT } & \text { telomerase reverse transcriptase }\end{array}$

main limitation of approaches based on a combined use of various markers to increase sensitivity. The current review summarizes data and potential applications of different types of urine markers, including cell-based markers, RNA markers, DNA markers, and protein markers. New technologies allowing quick and broad molecular analyses have been implemented in the context of urine markers to gain more information on tumor-associated alterations within a short period of time. These high-throughput technologies have a high potential of reaching some of the goals that have been set in the context of urinary diagnosis in BC.

\section{Cell-Based Bladder Markers}

Several cell-based urine markers are available, including conventional urinary cytology, ImmunoCyt/ $\mathrm{uCyt}+$ (Scimedx, Denville, US), fluorescence in situ hybridization (FISH) UroVysion (Abbott Molecular, des Plaines, US) and Cell Detect (Zetiq Technologies Ltd., Tel Aviv, Israel) (Table 1).

Urine cytology remains the gold standard and the only urine marker that is recommended by the European Association of Urology (EAU) and the American
Urological Association (AUA) [1,2] for the diagnosis and surveillance of high-grade BC (in combination with cystoscopy).

Overall, the reported sensitivity ranges from $20 \%$ to $97.3 \%$; specificity ranges from $74 \%$ to $99.5 \%$ [6-8]. Urine cytology has an excellent specificity with few false-positive cases for high-grade bladder cancer (HGBC) and carcinoma in situ (specificity 83\% to 99\%) $[1,9]$. Historically, urine cytology had a high sensitivity for HG disease, but more contemporary series reported sensitivity for cytology at $40.8 \%$ and $54.3 \%$ for $\mathrm{HG}[10,11]$. Furthermore, a low sensitivity in low-grade tumors represents a main downside of conventional cytology; therefore, it is not used to replace cystoscopy.

Immunocytology (Immunocyt [UCyt+], Scimedx, US) is based on immunoassays for detection of tumorassociated cell-based antigens. The global sensitivity of immunocytology ranges between $78 \%$ and $90 \%$ and is higher than that of cytology, especially for low-grade cancers, whereas its specificity has been reported as $68 \%$ to $87 \%$ and therefore tends to be lower than that of cytology [12-14] (Table 2).

ImmunoCyt/uCyt+ in patients whose cytology was atypical has been frequently discussed as a reflex test to avoid cystoscopy in patients with low-grade cancer since the test has a NPV of $83.7 \%[1,15]$. Nevertheless, Immunocyt/uCyt+ has been recently removed from the market.

Fluorescence in situ hybridization (multi-target multicolor FISH - UroVysion) (Abbott Molecular, US) allows the detection of chromosomal abnormalities that are frequently observed in malignant urothelial cells (gains in chromosomes 3, 7, 17 or deletions of chromosome 9). These assays have been shown to be more sensitive than cytology in detecting $\mathrm{BC}$ at the cost of a lower specificity. Sensitivity ranges from $50 \%$ to $88 \%$ and specificity from $78 \%$ to $92 \%$ [12-14], depending on

\section{TABLE 1.}

Summary of commercially available cell-basedt urinary markers

\begin{tabular}{l|l|l} 
Marker / Test & Marker / Test & Description
\end{tabular}

Scimedx, US

Immunocyt /uCyt+

UroVysion

Abbott Molecular, US

Multicolor FISH assay for detection of numerical aberrations of chromosomes 3, 7, 17 and locus 9p21

Immunocytochemical assay for detection of expression of carcinoembryonic antigen and $\mathrm{BC}$-associated mucins

Platform technology comprising a proprietary plant extract and 3 dyes that enables color discrimination between malignant (red) and benign (green) cells based on specific metabolic alterations exclusive to the tumor Israel
Zetiq Technologies
FDA status

Approved for follow-up; recently removed from the market

Approved for diagnosis and follow-up

Not approved 
TABLE 2.

Performance characteristics of cell-based urine markers

\begin{tabular}{|c|c|c|c|c|c|c|c|}
\hline & Study & $\begin{array}{c}\text { Patients } \\
n\end{array}$ & $\begin{array}{c}\text { Studies } \\
\text { included } \\
n\end{array}$ & Context & $\begin{array}{c}\text { Sensitivity } \\
\%\end{array}$ & $\underset{\%}{\text { Specificity }}$ & $\begin{array}{c}\text { Patients with } \\
\text { tumor } \\
n\end{array}$ \\
\hline \multirow{3}{*}{ Immuno-cytology } & $\begin{array}{c}\text { Chou et al. } \\
\text { [13] }\end{array}$ & 1876 & 7 & $\begin{array}{l}\text { Primary } \\
\text { diagnosis }\end{array}$ & $\begin{array}{c}85 \\
(78-90)\end{array}$ & $\begin{array}{c}83 \\
(77-87)\end{array}$ & 401 \\
\hline & $\begin{array}{c}\text { Mowatt et al. } \\
{[14]}\end{array}$ & 4199 & 10 & Mixed & $\begin{array}{c}84 \\
(77-91)\end{array}$ & $\begin{array}{c}75 \\
(68-83)\end{array}$ & NA \\
\hline & $\begin{array}{l}\text { Schmitz Drager } \\
\text { et al. [12] }\end{array}$ & 4899 & 20 & Mixed & $\begin{array}{c}81 \\
\text { (Median) }\end{array}$ & $\begin{array}{c}75 \\
\text { (Median) }\end{array}$ & 1252 \\
\hline \multirow{3}{*}{ UroVysion } & $\begin{array}{c}\text { Chou et al. } \\
\text { [13] }\end{array}$ & 651 & 2 & $\begin{array}{l}\text { Primary } \\
\text { diagnosis }\end{array}$ & $\begin{array}{c}73 \\
(50-88)\end{array}$ & $\begin{array}{c}95 \\
(87-98)\end{array}$ & 144 \\
\hline & $\begin{array}{c}\text { Mowatt et al. } \\
{[14]}\end{array}$ & 3321 & 14 & Mixed & $\begin{array}{c}76 \\
(65-8)\end{array}$ & $\begin{array}{c}85 \\
(78-92)\end{array}$ & NA \\
\hline & $\begin{array}{c}\text { Schmitz- } \\
\text { Drager et al. } \\
{[12]}\end{array}$ & 2852 & 21 & Mixed & $\begin{array}{c}72 \\
\text { (Median) }\end{array}$ & $\begin{array}{c}80 \\
\text { (Median) }\end{array}$ & 792 \\
\hline Cell Detect & $\begin{array}{c}\text { Davis et al. } \\
{[24]}\end{array}$ & 217 & 1 & Surveillance & 84 & 84 & 96 \\
\hline
\end{tabular}

the $\mathrm{BC}$ prevalence in the cohort of the study (Table 3) and also on the criteria of positive tests. FISH sensitivity was reported to be twice as high as cytology for nonmuscle invasive bladder cancer (NMIBC) (50.9\% versus $29.8 \%$ ) $[16,17]$ and triple (73\% versus $24 \%$ ) when scoring criteria have been modified. Notably the scoring algorithm of the manufacturer was developed for voided urine but was modified for bladder washings $[17,18]$.

In patients with atypical cytology or indeterminate cystoscopy, UroVysion may help to identify those who would need further evaluation since 2 prospective studies found a higher likelihood of cancer in patients with positive markers with a reasonable positive predictive value $[19,20]$. This role has been included in the AUA guidelines as a potential use of urine markers. There is evidence from various sources that anticipatory false-positive results exist. Patients with positive FISH but no visible tumor in cystoscopy were reported to be at increased risk for recurrence and progression $[21,22]$. Persisting positive FISH during Bacillus CalmetteGuérin (BCG) immunotherapy increased the risk of recurrence and progression [23]. Recently, 2 multicenter prospective studies confirmed the predictive value of FISH in detecting recurrence and progression in HGBC treated with BCG $[10,25]$. A positive FISH at initiation or completion of BCG is associated with 3 -fold higher rate of recurrence but results in individual patients vary, which makes it challenging to make clinical decisions on the basis of FISH results [26].

The platform CellDetect (Zetiq Technologies, Israel) uses a proprietary plant extract and 3 dyes that enable color discrimination between malignant (red) and benign (green) cells on the basis of specific metabolic alterations associated with BC. In a multicenter validation study, the test reached a sensitivity of $84 \%$ (Table 3) (78\% for detecting LG NMIBC). The specificity was $84 \%$ in patients undergoing surveillance by cystoscopy [24].

\section{DNA-Based Markers}

Various types of DNA alterations can occur in BC, such as mutations, copy number alterations, and genomic rearrangements. In general, $\mathrm{BC}$ is known to have a high mutational burden [27,28]. Until now, none of the DNA-based urine assays that are based on detection of mutations have been FDA approved for use in clinic. Prospective validation of most urine assays is still awaited.

Some of the most frequently found DNA mutations in $\mathrm{BC}$ include mutations in the FGFR3, RAS, PIK3CA, and TERT genes. Approximately two-thirds of NMIBCs have activating FGFR3 mutations. The number of 
TABLE 3.

Performance of assays that are based on detection of DNA alterations

\begin{tabular}{|c|c|c|c|c|c|c|c|}
\hline Assay Parameters & Author & Year & Technique & $\begin{array}{c}\text { Patients } \\
n\end{array}$ & Population & $\begin{array}{c}\text { Sens } \\
\%\end{array}$ & $\begin{array}{c}\text { Spec } \\
\%\end{array}$
\end{tabular}

Mutation: FGFR3, PIK3CA, RAS

Methylation: $41 \mathrm{CpG}$ islands in 23 genes

Microsatellite: 12 different primers
SNaPshot analysis

Zuiverloon et al. 36]

2013

Methylation Specific multiplex ligationdependent probe amplification
Surveillance

- FGFR3

- Cytology

- FGFR3 + cytology

- FGFR3 + Microsatellite

- FGFR3 + Methylation

136

Surveillance, patients stratified by inclusion tumor

- FGFR3

- FGFR3 + PIK3CA + RAS

66

- Microsatellite

- FGFR3 + Microsatellite

- Methylation

- FGFR3 + Methylation
49
Mutation: FGFR3

Methylation:OTX1, ONECUT2 OSR1
Kandimalla et al. [37] et
2013 SNaPshot analysis

\begin{tabular}{|c|c|c|}
\hline $\begin{array}{l}\text { Roprech } \\
\text { et al. [38] }\end{array}$ & 2016 & $\begin{array}{l}\text { Allele specific } \\
\text { PCR Quantitative } \\
\text { multiplex- } \\
\text { methylation } \\
\text { specific PCR }\end{array}$ \\
\hline
\end{tabular}

Age, smoking status

Methylation: HS3ST2, SLIT2, SEPTIN9
Clinical parameters:

Mutation: FGFR3

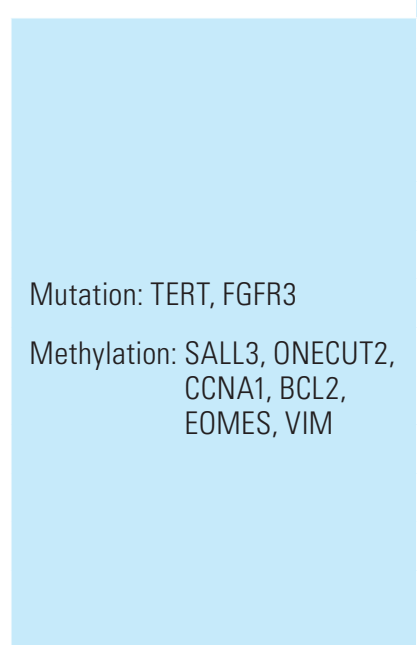

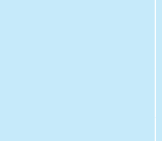

Dahmcke et al. [39]

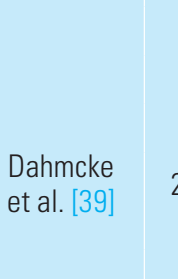

\section{Surveillance}

- Methylation only

- Combined

74

90

79

77 
TABLE 3.

Performance of assays that are based on detection of DNA alterations, Cont'd

\begin{tabular}{|l|l|l|l|l|l|c|}
\hline Assay Parameters & Author & Year & Technique & $\begin{array}{c}\text { Patients } \\
n\end{array}$ & $\begin{array}{c}\text { Population } \\
\%\end{array}$ & $\begin{array}{c}\text { Spec } \\
\%\end{array}$
\end{tabular}

Mutation: FGFR3, TERT

Methylation: OTX1

\section{Beukers}

et al. [40]

2017 SNaPshot analysis
Surveillance

- Previous high grade

72

- Previous low grade

55

$57 \quad 59$

Mutation: FGFR3, TERT, HRAS

Methylation: OTX1, ONECUT2, Van Kessel TWIST1 et al. [41]

2016

SNaPshot analysis

Clinical parameter: Age

Mutation: FGFR3, TERT, HRAS

Methylation: OTX1, ONECUT2, TWIST1

Van Kessel et al. [42]

Clinical parameter: Age

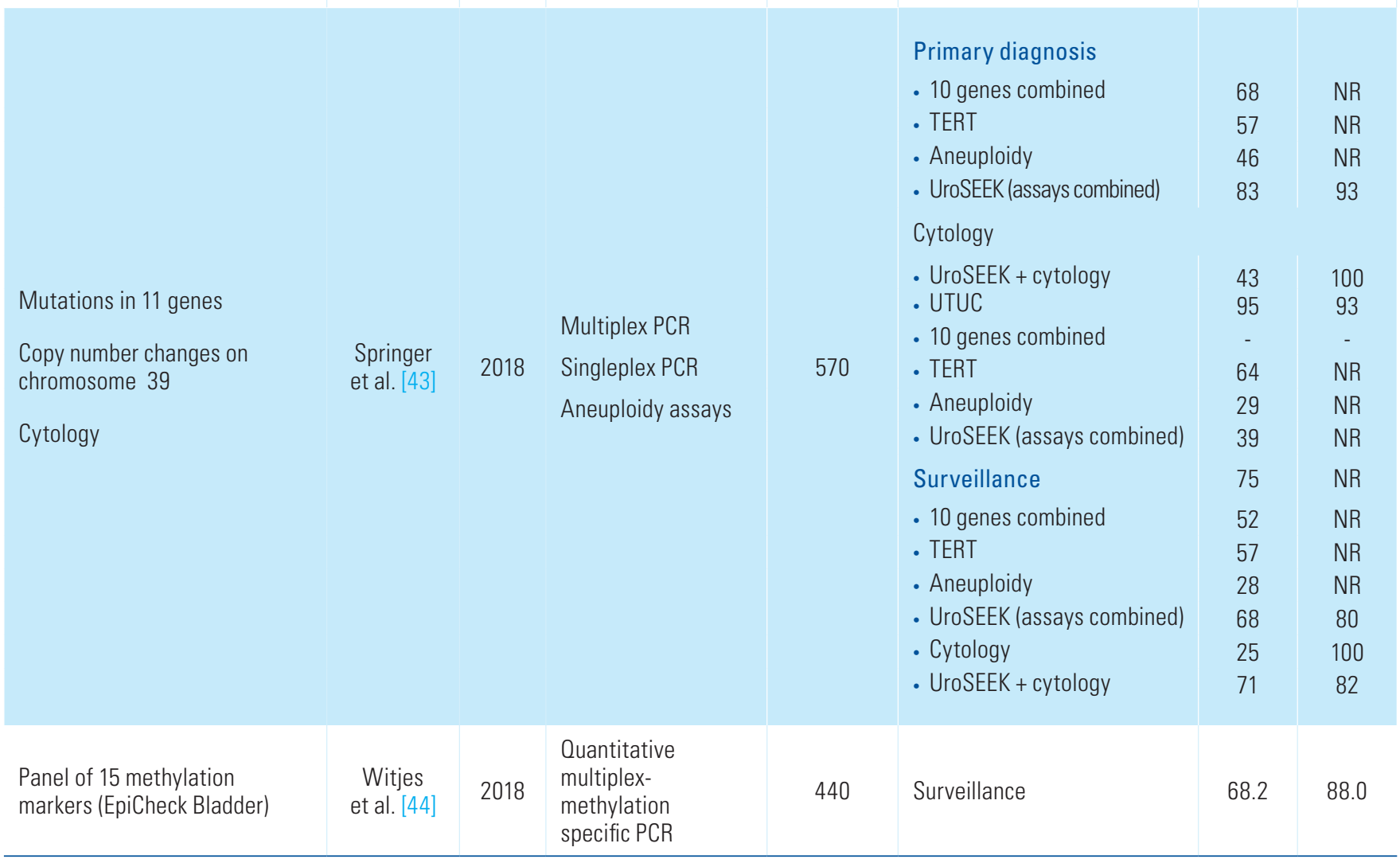

SNaPshot analysis

2017 Methylation-specific polymerase chain reaction (MSP)
200

Hematuria

93

86

83 polymerase chain reaction (MSP)

154 Hematuria

97 $x^{2}$ 
Further, approximately $20 \%$ of BC tumors harbor a mutation in the PIK3CA gene [27]. PI3K can be activated by RTKs, or via crosstalk via the RTK-RAS-MAPK pathway. Finally, mutations in the telomerase reverse transcriptase (TERT) gene are frequent in BC: $>70 \%$ of bladder tumors harbor a TERT promotor mutation [35]. The presence of a TERT mutation has been found to be more frequent in tumors that also harbored FGFR3 mutations; however, it was not associated with stage or grade of the tumors [35]. Overall, significant overlap between different mutations occurs.

Epigenetic studies, such as genome-wide methylation analyses, have identified several genes that are significantly hypermethylated in BC cells compared with normal urothelial cells [45]. Methylation of several genes was found to be useful for the diagnosis of $\mathrm{BC}$, with some markers being highly specific for BC. Gene hypermethylation has also been proposed in predicting disease progression $[46,47]$. The EpiCheck platform (Nucleix, Israel) has been designed for detection of DNA methylation changes associated with BC in a panel of 15 biomarkers. The test has been validated in several studies that included mainly patients who were under surveillance for NMIBC [39,40]. Other assays that were validated in several cohorts have been designed to combine the analysis of both $\mathrm{BC}$-relevant DNA gene methylations and mutations $[42,49]$. Assay results and clinical parameters (type of hematuria) have been incorporated in multivariate models to obtain optimal performance.

In the literature, various DNA-based urinary markers have been developed. For most of these, prospective validation is still lacking. The urine-based markers suggested in the literature can be subdivided into markers used for detection of primary tumors (eg, in a patient with hematuria) and markers used for detection of recurrent tumors (eg, patient previously treated for BC). Furthermore, markers based on cell pellet DNA exist, as well as cell-free DNA-based markers Table 3. provides an overview of studies that combine various DNA marker assays.

\section{RNA-Based Markers}

A high number of RNA-based urinary gene panels are being validated, with the aim of improving diagnostic accuracy in $\mathrm{BC}$ without decreasing specificity [3]. Three messenger RNA (mRNA)-based urinary biomarkers (Cxbladder assay [Pacific Edge Diagnostics, US], GeneXpert BC [Cepheid, US], and TaqMan Array, [ThermoFisher, US]) and various microRNA (miRNA)-based urinary targets (eg, members of the miRNA-200 family and miRNA-145) are currently tested in clinical trials for $\mathrm{BC}$ detection or surveillance.

In detail, 5 published studies [50-53] on different clinical scenarios (detection of BC in risk population, and surveillance for recurrent $\mathrm{BC}$ ) consistently confirmed promising diagnostic performances with a high sensitivity (even in LG tumors on surveillance) and NPV of the Cxbladder assay at the expense of a lower specificity than cytology. For BC screening and detection, the Cxbladder has the potential to reduce the frequency of diagnostic and invasive procedures in patients presenting with hematuria; however, further prospective validation studies are necessary. The GeneXpertBC test has shown $83 \%$ to $100 \%$ sensitivity for $\mathrm{HG}$ tumors and up to $77 \%$ sensitivity for LG tumors, and overall sensitivity ranged between $46.2 \%$ and $84 \%$. Whereas the specificity in the $\mathrm{BC}$ detection population was very high (90\% to $95 \%)$, in homogeneous data specificity was confirmed for BC surveillance $(77 \%$ to $91 \%)[11,54-56]$.The training and validation study analyzing the diagnostic accuracy of a specific $12+2$ gene set (TaqMan Array) panel on bladder washings and voided urine samples showed consistently high sensitivities and specificities in BC detection (sensitivity: $70 \%, 80 \%$, and $98 \%$; specificity: $86 \%, 96 \%$, and $99 \%$ ) and for discrimination between LG and HG tumors (sensitivity: $75 \%$ to $79 \%$; specificity: $75 \%$ to $92 \%$ ) [50,51]. These findings were confirmed in a prospective, blinded multicenter trial [59]. An overview of the diagnostic performance characteristics of the 3 mRNA-based urine assays for detection/surveillance of $\mathrm{BC}$ is shown in Table 4.

Moreover, miRNAs may become biomarkers for $\mathrm{BC}$ detection and surveillance in the future. Nevertheless, identified miRNA signatures were found to be heterogenous in published studies, with few trials confirming their results by independent validation cohorts, resulting in a low degree of reproducibility in the clinical setting. Most trials included only a small number of patients ( $\mathrm{n}=47$ to 207) $[60,61]$. Another controversial issue that is discussed controversially is the feasibility of implementation and application of different analytical platforms and bioinformatics in the clinical setting [62].

In summary, RNA-based urinary markers are characterized by ease of handling, their brief hands-on sample preparation time, technical instrument systems that automate and integrate all complex PCR processes, and high-quality standards including in-sample quality controls [55]. One of the major limitations of the application of RNA-based urinary techniques is the difficulty in obtaining sufficient quantity of "highquality" RNA from voided urine compared with bladder washings. Studies using bladder washings and optimized specimen collection and handling may achieve results that are not attainable in real world practice $[57,63]$. It has been shown that bladder washing samples yielded higher amounts of better RNA-quality than voided urine 
TABLE 4.

Diagnostic performance characteristics of mRNA-based urine markers for detection/surveillance of BC

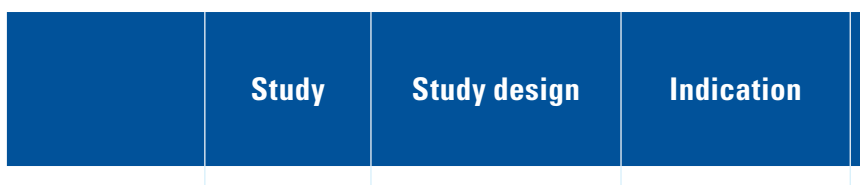

\begin{tabular}{|c|c|c|c|c|}
\hline $\begin{array}{c}\text { Patients } \\
\mathbf{n}\end{array}$ & SN & $\begin{array}{c}\text { SN for } \\
\text { HG tumors }\end{array}$ & $\begin{array}{c}\text { SP } \\
\%\end{array}$ & $\begin{array}{c}\text { NPV } \\
\%\end{array}$ \\
\hline
\end{tabular}

Cxbladder

O'Sullivan Marker-comparison et al. [51] study, prospective

Microhematuria

485

82

97

85

\begin{tabular}{|c|c|c|c|c|c|c|c|c|}
\hline & $\begin{array}{l}\text { Lotan } \\
\text { et al. [53] }\end{array}$ & $\begin{array}{l}\text { Marker-comparison } \\
\text { study, prospective }\end{array}$ & BC surveillance & 803 & 91 & 97 & - & 96 \\
\hline \multirow[t]{2}{*}{ G + PINDEX } & $\begin{array}{l}\text { Kavalieris } \\
\text { et al. [50] }\end{array}$ & Cohort, prospective & $\begin{array}{c}\text { Micro- and } \\
\text { Macrohematuria }\end{array}$ & $\begin{array}{c}\text { 695/ (MAH) } \\
45 \text { (MIH) }\end{array}$ & 95 & & 45 & 98 \\
\hline & $\begin{array}{l}\text { Kavalieris } \\
\text { et al. [52] }\end{array}$ & Cohort, prospective & BC surveillance & 763 & 93 & 97 & - & 97 \\
\hline \multirow[t]{4}{*}{ GeneXpert BC } & $\begin{array}{c}\text { Van } \\
\text { Valenberg } \\
\text { et al. [11] }\end{array}$ & $\begin{array}{l}\text { Marker-comparison } \\
\text { study, prospective }\end{array}$ & $\begin{array}{l}\text { BC detection + } \\
\text { surveillance }\end{array}$ & $\begin{array}{l}239 \text { (surveillance)/ } \\
508 \text { (detection) }\end{array}$ & 74 & 83 & $\begin{array}{l}80 \text { (surveillance) } \\
95 \text { (detection) }\end{array}$ & 93 \\
\hline & $\begin{array}{l}\text { Wallace } \\
\text { et al. [54] }\end{array}$ & Cohort, prospective & $\begin{array}{l}\text { BC detection, } \\
\text { surveillance }\end{array}$ & $\begin{array}{l}484 \text { (training cohort) + } \\
450 \text { (validation cohort) }\end{array}$ & 73 & - & $\begin{array}{c}90 \text { (hematuria) } \\
77 \text { (surveillance) }\end{array}$ & - \\
\hline & $\begin{array}{l}\text { Pichler } \\
\text { et al. [55] }\end{array}$ & $\begin{array}{l}\text { Marker-comparison } \\
\text { study, prospective }\end{array}$ & BC surveillance & 140 & 84 & 100 & 91 & 93 \\
\hline & $\begin{array}{l}\text { D'Elia } \\
\text { et al. [56] }\end{array}$ & $\begin{array}{l}\text { Marker-comparison } \\
\text { study, prospective }\end{array}$ & BC surveillance & 230 & 46.2 & 85.7 & 77 & 83 \\
\hline \multirow[t]{3}{*}{$\begin{array}{l}\text { TaqMan Array } \\
(12+2 \text { gene } \\
\text { panel) }\end{array}$} & $\begin{array}{l}\text { Mengual } \\
\text { et al. [57] }\end{array}$ & Cohort, prospective & BC detection & $\begin{array}{l}341 / 235 \\
\text { (control) }\end{array}$ & 98 & 100 & 99 & 95 \\
\hline & $\begin{array}{l}\text { Mengual } \\
\text { et al. [58) }\end{array}$ & Case-control study & $\mathrm{BC}$ detection & $\begin{array}{l}207 \\
\text { (independent set)/ } \\
404 \text { (training set) }\end{array}$ & 80 & - & 86 & - \\
\hline & $\begin{array}{l}\text { Ribal } \\
\text { et al. [59] }\end{array}$ & Cohort, prospective & BC detection & 525 & 81.5 & - & 91.3 & - \\
\hline
\end{tabular}

BC: bladder cancer; HG: high grade; MAH: macrohematuria; MIH: microhematuria; NPV: negative predictive value; SN: sensitivity; SP: specificity. 


\section{TABLE 5.}

Overall performance rates of FDA approved urinary protein markers, based on the most recent available metaanalyses

Protein marker
Reference

Chou et al. [4]

NMP22 (Nuclear

Matrix Protein 22)
Context

Primary diagnosis
Sample Size

$\mathrm{n}=1313$ for ELISA;

$\mathrm{n}=1816$ for $\mathrm{POC}$
Sensitivity

67 (ELISA)

47 (POC)
Specificity

84 (ELISA)

93 (POC)

\begin{tabular}{|c|c|c|c|c|c|}
\hline & Mowatt et al. [65] & $\begin{array}{l}\text { Diagnosis of primary } \\
\text { and prevalent cancer }\end{array}$ & $\begin{array}{c}\mathrm{n}=10119 \text {-ELISA } \\
\text { and POC }\end{array}$ & 68 (overall) & 79 (overall) \\
\hline \multirow{2}{*}{$\begin{array}{l}\text { BTA (Complement factor } \\
\text { H-related protein and } \\
\text { complement factor } \mathrm{H} \text { ) }\end{array}$} & Chou et al. [4] & $\begin{array}{c}\text { Diagnosis of primary } \\
\text { cancer }\end{array}$ & $n=1021(P O C)$ & 76 & 78 \\
\hline & Guo et al. [66] & $\begin{array}{l}\text { Diagnosis of primary } \\
\text { and prevalent cancer }\end{array}$ & $n=3175(P O C)$ & 67 & 75 \\
\hline
\end{tabular}

POC: Point of care assay

samples [57]. Another limitation is the fact that there is a wide variability in the cost of RNA-based urine tests. For widespread use in the future, these tests should be available at reasonable cost. Another challenge of RNAbased urinary markers in preanalytics is the mRNA instability, resulting in an advantage for commercial test systems (working with RNA-stabilizing tubes) compared with single urinary mRNA targets (CAIX or survivin). Standardized processes are indispensable for RNA analysis. According to the current EAU and AUA guidelines, RNA-based urinary biomarkers cannot be recommended for screening, detection of $\mathrm{BC}$ in patients with microscopic hematuria, or BC surveillance $[2,64]$.

\section{Protein Markers}

In comparison with other-omics, the proteome can be directly linked to a phenotype, and hence represents a rich source of biomarkers and therapeutic targets (the latter, however, typically not in urine). On the downside, the extensive complexity and large dynamic range of protein components of a biological sample (in the case of urine, spanning at least 6 orders of magnitude) raise technical challenges, regularly encountered to some extent in proteome analysis and addressed, via the application of high-resolution mass spectrometry-based methodologies [67]. A large number of proteins have been reported in association with $\mathrm{BC}$ phenotypes, for disease prognosis or treatment prediction [68-71].
Of the most widely studied, nuclear matrix protein 22 (NMP22), quantified by the point-of-care NMP22 BladderChek, and the NMP22 ELISA immunoassay (Alere/Abbott), has received approval by the FDA for application in BC surveillance (both tests) and detection of the disease in high-risk or symptomatic populations (for the NMP22 BladderChek test only). Similarly, the BTA TRAK immunoassay-based and BTA STAT pointof-care tests (Polymedco), detecting the complement factor $\mathrm{H}$ and complement factor $\mathrm{H}$-related protein, have also been granted FDA approval for use in BC diagnosis and surveillance. Meta-analyses of existing studies demonstrate that the performance for both approved markers varies widely among the studies (ranging for the sensitivities and specificities from $47 \%$ to $>90 \%$ ) [65,68-72] (Table 5). The reported sensitivities are higher than those of cytology in the detection of lowgrade disease, but hematuria, infections, presence of stones or instrumentation are frequent confounders, compromising the specificity of the assays [73].

Besides the abovementioned FDA-approved tests, several additional exploratory protein biomarkers have been reported in primary diagnosis, and in cancer detection during surveillance and/or monitoring of treatment response. Among the most frequently reported are proteins of the extracellular and the nuclear matrix, apolipoproteins (apolipoprotein A-I, apolipoprotein A-II, apolipoprotein E) and other plasma proteins (alpha 
1 anti-trypsin, heparin cofactor II), including angiogenic factors (such as angiogenin, vascular endothelial growth factor A-VEGFA), as well as inflammatory factors (such as interleukins $2,6,8,10, \mathrm{TNF} \alpha)[68,70]$. Commercially available assays for the measurement of some of these proteins have been established; these include the UBC Rapid, (IDL Biotech AB) or CYFRA 21-1 (Cisbio International) tests measuring cytokeratin fragmentsmainly of cytokeratins 8 and 18 for the former [74] and cytokeratin 19 for the latter [75] — or ADXBLADDER, (Arquer Diagnostics Ltd), quantifying the levels of the mini-chromosome maintenance-MCM 5 protein [76], having being tested mainly in diagnostic contexts of use and, as essentially with all tests, exhibiting better performance in advanced than in early grade and stage tumors.

Applications in disease prognosis have also been described, including the recent examples of the shed ectodomains of epithelial cell adhesion molecule (EpCAM) and hepatocyte growth factor activator inhibitor-1 (HA-1), exhibiting a prognostic value for disease-specific death (in the range of 2 times increased risk at increased marker levels) in NMIBC [77]; or various interleukins (such as IL12, TRAIL, TNF $\alpha$ ) in response to BCG treatment [78].

A clear consensus is emerging that combination of individual protein markers with clinicopathological information $[79,80]$ in biomarker panels or multiparametric classifiers results in increased accuracy rates. Examples include the CyPRIT (cytokine panel for response to intravesical therapy) measuring the levels of 9 cytokines, as a predictor of response to BCG treatment in intermediate- and high-risk NMIBC [78]; or the simultaneous quantification of matrix metalloproteases and plasma proteins via ELISA-based assays in diagnostic contexts of use $[68,81]$ (Table 6$)$. In addition, peptides mainly originating from extracellular matrix proteins (collagens, fibrinogen) but also plasma proteins quantified simultaneously via mass spectrometry-based assays and combined to a classifier (DiaPat) have shown diagnostic value in disease primary detection and surveillance [82].

Collectively, several urinary protein markers in association with $\mathrm{BC}$ phenotypes and prognostic/ predictive contexts of use have been reported. Proper prospective validation is pending to define their added value (stand-alone or in combination) in disease management. Technology advancements allowing the simultaneous detection of marker panels provide a solid basis for future work in this direction.

\section{Clinical Considerations for Use of Urinary Molecular Markers in Context of BC}

The various marker tests differ regarding their potential applications in the diagnosis and surveillance of BC. Whereas FISH, immunocytology, and NMP22 have long been considered the most valuable alternatives to cytology, other DNA- and RNA-based assays have drawn broad attention within the last 10 years. With the advent of high-throughput analysis technologies there is the hope that performing multiple analyses in parallel with high resolution will improve the detection rate. Many of these test systems provide information on DNA, RNA, and protein levels. In the future, such information can be helpful not only in the detection of $\mathrm{BC}$ but also for the non-invasive monitoring of disease. One potential indication that has been investigated in the context of the UroVysion is the monitoring of patients treated with BCG. Because of the high risk of recurrence in these patients, a marker that provides evidence of response or failure of treatment would be of high value to prevent delay of cystectomy in patients who

TABLE 6.

Exploratory marker panels for protein-based $\mathrm{BC}$ detection

\begin{tabular}{|c|c|c|c|c|c|}
\hline Protein marker & Reference & Context & Sample Size & Sensitivity, \% & Specificity, \% \\
\hline $\begin{array}{c}\text { Cytokine panel } \\
\text { (9 cytokines; CyPRIT) }\end{array}$ & $\begin{array}{l}\text { Kamat } \\
\text { et al. [78] }\end{array}$ & $\begin{array}{l}\text { NMIBC prediction of } \\
\text { recurrence }\end{array}$ & $n=130$ & 80 & 77.4 \\
\hline
\end{tabular}

\begin{tabular}{c|c|c|c|c|}
\hline $\begin{array}{c}10 \text { protein panel } \\
\text { (Meso Scale Diagnostic) }\end{array}$ & $\begin{array}{c}\text { Shimizu } \\
\text { et al. [81] }\end{array}$ & $\begin{array}{c}\text { Diagnosis of primary } \\
\text { cancer }\end{array}$ & $\mathrm{n}=200$ & 85 \\
\hline $\begin{array}{c}\text { CE-MS Peptide panel } \\
\text { (DiaPat) }\end{array}$ & $\begin{array}{c}\text { Frantzi } \\
\text { et al. [82] }\end{array}$ & $\begin{array}{c}\text { Diagnosis of primary } \\
\text { and prevalent cancer } \\
\text { (test set } n=481)\end{array}$ & $\mathrm{n}=481$ (test set) & $\begin{array}{c}91 \text { (primary) } \\
87 \text { (prevalent) }\end{array}$ \\
\hline
\end{tabular}


do not respond to BCG. The high level of complexity of new marker combination panels is associated with various challenges. One main challenge of any combination marker panel that is developed with the goal of achieving a high sensitivity will be to avoid falsepositive test results, which has been a major issue in the development of many markers that have been discussed as potential alternatives for cytology.

Any marker or test system that is supposed to be broadly implemented in clinical practice requires prospective clinical trials to address the value of the test in the relevant clinical context. Case-control studies provide preliminary information on test characteristics but will not be sufficient for a broad clinical use. A common study design used for validation of promising markers is to analyze urine samples prospectively from patients undergoing cystoscopy because of suspicion of BC. One of the primary goals of urine biomarkers in this context is to replace cystoscopy, but the cohorts studied are typically too heterogenous with respect to the indication for evaluation (gross hematuria, microscopic hematuria, or irritative voiding symptoms), so that the study results are not adequate to change practice. Moreover, many studies include both patients undergoing primary diagnostic workup and those under surveillance. Such heterogeneity potentially explains the considerable differences of test performances between different validation studies. To avoid such heterogeneity of patient groups, it makes sense to test the potential of urine markers in specific clinical settings. Both clinicians and companies should make every effort to validate an assay in a prospective

\section{References}

1. Babjuk M, Burger M, Comperat EM, et al. European Association of Urology Guidelines on Non-muscle-invasive BC (TaT1 and Carcinoma In Situ) - 2019 Update. Eur Urol. 2019;76(5):639-57.

2. Chang SS, Boorjian SA, Chou R, et al. Diagnosis and treatment of non-muscle invasive BC: AUA/SUO Guideline. J Urol. 2016;196(4):1021-9

3. Maas M, Bedke J, Stenzl A, Todenhofer T. Can urinary biomarkers replace cystoscopy? World J Urol. 2019;37(9):1741-9.

4. Chou R, Gore JL, Buckley D, et al. Urinary biomarkers for diagnosis of BC: a systematic review and meta-analysis. Ann Intern Med. 2015;163(12):922-31.

5. Soria F, Krabbe LM, Todenhofer T, et al. Molecular markers in BC. World J Urol. 2019;37(1):31-40.

6. Murphy WM, Crabtree WN, Jukkola AF, Soloway MS. The diagnostic value of urine versus bladder washing in patients with $\mathrm{BC}$. J Urol. 1981;126(3):320-2.

7. Brown FM. Urine cytology. It is still the gold standard for screening? Urol Clin North Am. 2000;27(1):25-37. trial designed in cooperation with guideline panels and key opinion leaders. One example of a prospective trial that has been set up in a specific setting with a specific hypothesis is the UroFollow trial [83]. In this trial, patients with low grade NMIBC are randomized to receive standard of care surveillance using cystoscopy versus regular measurement of urine markers (including cytology and UroVysion), with cystoscopies performed only in the case of a positive marker or clinical signs of recurrence. The hypothesis of the trial is that a urinary marker-based follow-up is non-inferior to a cystoscopybased follow-up with respect to detection of recurrence and progression.

Another clinical trial (NCT03988309) is randomizing patients to a marker-based approach using Cxbladder versus a standard evaluation for patients with hematuria. The goal of the trial is to determine if a risk-based approach with the addition of a marker is superior to cystoscopy for all patients.

Such specific study designs will not only allow a better understanding of the performance of an assay but also provide data on the potential use of a specific test.

\section{Conclusions}

Changing current clinical practice in bladder cancer workup is a very ambitious goal for any biomarker. There is currently no urinary marker available for which there is sufficient evidence to indicate it may change our current diagnostic workup, which includes cystoscopy and cytology. New markers should be considered for a use in more specific indications and clinical settings to allow the setup of properly designed trials.

8. Bastacky S, Ibrahim S, Wilczynski SP, Murphy WM. The accuracy of urinary cytology in daily practice. Cancer. 1999;87(3):118-28.

9. Brimo F, Vollmer RT, Case B, Aprikian A, Kassouf W, Auger M. Accuracy of urine cytology and the significance of an atypical category. Am J Clin Pathol. 2009;132(5):785-93.

10. Freifeld Y, Lotan Y. Effect of blue-light cystoscopy on contemporary performance of urine cytology. BJU Int. 2019;124(2):251-7.

11. Valenberg F, Hiar AM, Wallace $E$, et al. Prospective validation of an mRNA-based urine test for surveillance of patients with $B C$. Eur Urol. 2019;75(5):853-60.

12. Schmitz-Drager BJ, Droller M, Lokeshwar VB, et al. Molecular markers for BC screening, early diagnosis, and surveillance: the WHO/ICUD consensus. Urol Int. 2015;94(1):1-24.

13. Chou R, Gore JL, Buckley D, et al. Urinary biomarkers for diagnosis of BC: a systematic review and meta-analysis. Ann Intern Med. 2015;163(12):922-31. 
14. Mowatt G, Zhu S, Kilonzo M, et al. Systematic review of the clinical effectiveness and cost-effectiveness of photodynamic diagnosis and urine biomarkers (FISH, ImmunoCyt, NMP22) and cytology for the detection and follow-up of BC. Health Technol Assess. 2010;14(4):1-331, iii-iv.

15. Odisho AY, Berry AB, Ahmad AE, Cooperberg MR, Carroll PR, Konety BR. Reflex ImmunoCyt testing for the diagnosis of $\mathrm{BC}$ in patients with atypical urine cytology. Eur Urol. 2013;63(5):936-40.

16. Bubendorf L, Grilli B, Sauter G, Mihatsch MJ, Gasser TC, Dalquen P. Multiprobe FISH for enhanced detection of BC in voided urine specimens and bladder washings. Am J Clin Pathol. 2001;116(1):79-86.

17. Bubendorf L, Grilli B. UroVysion multiprobe FISH in urinary cytology. Methods Mol Med. 2004;97:117-31.

18. Zellweger T, Benz G, Cathomas G, Mihatsch MJ, Sulser T, Gasser TC, et al. Multi-target fluorescence in situ hybridization in bladder washings for prediction of recurrent BC. Int $\mathrm{J}$ Cancer. 2006;119(7):1660-5.

19. Schlomer BJ, Ho R, Sagalowsky A, Ashfaq R, Lotan Y. Prospective validation of the clinical usefulness of reflex fluorescence in situ hybridization assay in patients with atypical cytology for the detection of urothelial carcinoma of the bladder. J Urol. 2010;183(1):62-7.

20. Lotan Y, Bensalah K, Ruddell T, Shariat SF, Sagalowsky Al, Ashfaq R. Prospective evaluation of the clinical usefulness of reflex fluorescence in situ hybridization assay in patients with atypical cytology for the detection of urothelial carcinoma of the bladder. J Urol. 2008;179(6):2164-9.

21. Seideman C, Canter D, Kim P, et al. Multicenter evaluation of the role of UroVysion FISH assay in surveillance of patients with BC: does FISH positivity anticipate recurrence? World J Urol. 2015;33(9):1309-13.

22. Gopalakrishna A, Fantony JJ, Longo TA, et al. Anticipatory positive urine tests for BC. Ann Surg Oncol. 2017;24(6):1747-53.

23. Kamat AM, Dickstein RJ, Messetti $F$, et al. Use of fluorescence in situ hybridization to predict response to bacillus CalmetteGuerin therapy for BC: results of a prospective trial. J Urol. 2012;187(3):862-7.

24. Davis N, Shtabsky A, Lew S, et al. A novel urine-based assay for bc diagnosis: multi-institutional validation study. Eur Urol Focus. 2018;4(3):388-94.

25. Liem E, Oddens JR, Vernooij RWM, et al. The role of fluorescence in situ hybridization for predicting recurrence after adjuvant bacillus Calmette-Guerin in Patients with intermediate and high risk nonmuscle invasive $\mathrm{BC}$ : a systematic review and meta-analysis of individual patient data. J Urol. 2020;203(2):283-91.

26. Lotan Y, Inman BA, Davis LG, et al. Evaluation of the fluorescence in situ hybridization test to predict recurrence and/or progression of disease after bacillus Calmette-Guerin for primary high grade nonmuscle invasive $\mathrm{BC}$ : results from a prospective multicenter trial. J Urol. 2019;202(5):920-6.

27. Robertson AG, Kim J, Al-Ahmadie H, et al. Comprehensive molecular characterization of muscle-invasive BC. Cell. 2017;171(3):540-56 e25.
28. Cancer Genome Atlas Research N. Comprehensive molecular characterization of urothelial bladder carcinoma. Nature. 2014;507(7492):315-22.

29. van Rhijn BW, Zuiverloon TC, Vis AN, et al. Molecular grade (FGFR3/MIB-1) and EORTC risk scores are predictive in primary non-muscle-invasive BC. Eur Urol. 2010;58(3):433-41.

30. Tomlinson DC, Baldo 0, Harnden P, Knowles MA. FGFR3 protein expression and its relationship to mutation status and prognostic variables in BC. J Pathol. 2007;213(1):91-8.

31. Hernandez S, Lopez-Knowles E, Lloreta J, et al. Prospective study of FGFR3 mutations as a prognostic factor in nonmuscle invasive urothelial bladder carcinomas. J Clin Oncol. 2006;24(22):3664-71.

32. van Rhijn BW, Vis AN, van der Kwast TH, et al. Molecular grading of urothelial cell carcinoma with fibroblast growth factor receptor 3 and MIB-1 is superior to pathologic grade for the prediction of clinical outcome. J Clin Oncol. 2003;21(10):1912-21.

33. Burger $M$, van der Aa MN, van Oers JM, et al. Prediction of progression of non-muscle-invasive BC by WHO 1973 and 2004 grading and by FGFR3 mutation status: a prospective study. Eur Urol. 2008;54(4):835-43.

34. Downward J. Targeting RAS signalling pathways in cancer therapy. Nat Rev Cancer. 2003;3(1):11-22.

35. Allory Y, Beukers W, Sagrera A, et al. Telomerase reverse transcriptase promoter mutations in BC: high frequency across stages, detection in urine, and lack of association with outcome. Eur Urol. 2014;65(2):360-6.

36. Zuiverloon TC, Beukers W, van der Keur KA, et al. Combinations of urinary biomarkers for surveillance of patients with incident nonmuscle invasive BC: the European FP7 UROMOL project. J Urol. 2013;189(5):1945-51.

37. Kandimalla R, Masius R, Beukers W, et al. A 3-plex methylation assay combined with the FGFR3 mutation assay sensitively detects recurrent BC in voided urine. Clin Cancer Res. 2013;19(17):4760-9.

38. Roperch JP, Grandchamp B, Desgrandchamps F, et al. Promoter hypermethylation of HS3ST2, SEPTIN9 and SLIT2 combined with FGFR3 mutations as a sensitive/specific urinary assay for diagnosis and surveillance in patients with low or high-risk non-muscleinvasive BC. BMC Cancer. 2016;16:704.

39. Dahmcke CM, Steven KE, Larsen LK, et al. A prospective blinded evaluation of urine-dna testing for detection of urothelial bladder carcinoma in patients with gross hematuria. Eur Urol. 2016;70(6):916-9.

40. Beukers W, van der Keur KA, Kandimalla R, et al. FGFR3, TERT and OTX1 as a urinary biomarker combination for surveillance of patients with $\mathrm{BC}$ in a large prospective multicenter study. J Urol. 2017;197(6):1410-8.

41. van Kessel KE, Van Neste L, Lurkin I, Zwarthoff EC, Van Criekinge $W$. Evaluation of an epigenetic profile for the detection of $B C$ in patients with hematuria. J Urol. 2016;195(3):601-7.

42. van Kessel KE, Beukers W, Lurkin I, et al. Validation of a DNA methylation-mutation urine assay to select patients with hematuria for cystoscopy. J Urol. 2017;197(3 Pt 1):590-5. 
43. Springer SU, Chen $\mathrm{CH}$, Rodriguez Pena MDC, et al. Non-invasive detection of urothelial cancer through the analysis of driver gene mutations and aneuploidy. eLife. 2018;7:e32143 D0I: 10.7554/ elife.32143

44. Witjes JA, Morote J, Cornel EB, et al. Performance of the Bladder EpiCheck methylation test for patients under surveillance for non-muscle-invasive BC: results of a multicenter, prospective, blinded clinical trial. Eur Urol Oncol. 2018;1(4):307-13.

45. Kandimalla R, van Tilborg AA, Kompier LC, et al. Genome-wide analysis of $\mathrm{CpG}$ island methylation in BC identified TBX2, TBX3, GATA2, and ZIC4 as pTa-specific prognostic markers. Eur Urol. 2012;61(6):1245-56.

46. Beukers W, Kandimalla R, Masius RG, et al. Stratification based on methylation of TBX2 and TBX3 into three molecular grades predicts progression in patients with pTa-BC. Mod Pathol. 2015;28(4):515-22.

47. van Kessel KEM, van der Keur KA, Dyrskjot L, et al. Molecular markers increase precision of the European Association of Urology Non-Muscle-Invasive BC Progression Risk Groups. Clin Cancer Res. 2018;24(7):1586-93.

48. D'Andrea D, Soria F, Zehetmayer S, et al. Diagnostic accuracy, clinical utility and influence on decision-making of a methylation urine biomarker test in the surveillance of non-muscle-invasive BC. BJU Int. 2019;123(6):959-67.

49. van Kessel KEM, de Jong JJ, Ziel-van der Made ACJ, et al. A urine based genomic assay to triage patients with hematuria for cystoscopy. J Urol. 2020;204(1):50-7.

50. Kavalieris L, O'Sullivan PJ, Suttie JM, et al. A segregation index combining phenotypic (clinical characteristics) and genotypic (gene expression) biomarkers from a urine sample to triage out patients presenting with hematuria who have a low probability of urothelial carcinoma. BMC Urol. 2015;15:23.

51. O'Sullivan P, Sharples K, Dalphin M, et al. A multigene urine test for the detection and stratification of $\mathrm{BC}$ in patients presenting with hematuria. J Urol. 2012;188(3):741-7.

52. Kavalieris L, O'Sullivan P, Frampton C, et al. Performance characteristics of a multigene urine biomarker test for monitoring for recurrent urothelial carcinoma in a multicenter study. J Urol. 2017;197(6):1419-26.

53. Lotan Y, O'Sullivan P, Raman JD, et al. Clinical comparison of noninvasive urine tests for ruling out recurrent urothelial carcinoma. Urol Oncol. 2017;35(8):531 e15-e22.

54. Wallace E, Higuchi R, Satya M, et al. Development of a 90-minute integrated noninvasive urinary assay for BC detection. J Urol. 2018;199(3):655-62.

55. Pichler R, Fritz J, Tulchiner G, et al. Increased accuracy of a novel mRNA-based urine test for BC surveillance. BJU Int. 2018;121(1):29-37.

56. Elia CD, Pycha A, Folchini DM, et al. Diagnostic predictive value of Xpert BC Monitor in the follow-up of patients affected by non-muscle invasive BC. J Clin Pathol. 2019;72(2):140-4.

57. Mengual L, Burset M, Ribal MJ, et al. Gene expression signature in urine for diagnosing and assessing aggressiveness of bladder urothelial carcinoma. Clin Cancer Res. 2010;16(9):2624-33.
58. Mengual L, Ribal MJ, Lozano JJ, et al. Validation study of a noninvasive urine test for diagnosis and prognosis assessment of BC: evidence for improved models. J Urol. 2014;191(1):261-9.

59. Ribal MJ, Mengual L, Lozano JJ, et al. Gene expression test for the non-invasive diagnosis of $\mathrm{BC}$ : A prospective, blinded, international and multicenter validation study. Eur J Cancer. 2016;54:131-8.

60. Sapre N, Macintyre G, Clarkson M, et al. A urinary microRNA signature can predict the presence of bladder urothelial carcinoma in patients undergoing surveillance. Br J Cancer. 2016;114(4):454-62.

61. Yun SJ, Jeong P, Kim WT, et al. Cell-free microRNAs in urine as diagnostic and prognostic biomarkers of BC. Int $\mathrm{J}$ Oncol. 2012;41(5):1871-8.

62. Backes C, Meese E, Keller A. Specific miRNA Disease biomarkers in blood, serum and plasma: challenges and prospects. Mol Diagn Ther. 2016;20(6):509-18.

63. Klatte T, Shariat SF. Novel urinary markers for detection of BC-are we failing? J Urol. 2014;191(1):9-10.

64. Babjuk M, Bohle A, Burger M, et al. EAU Guidelines on Non-Muscleinvasive Urothelial Carcinoma of the Bladder: Update 2016. Eur Urol. 2017;71(3):447-61.

65. Mowatt G, Zhu S, Kilonzo M, et al. Systematic review of the clinical effectiveness and cost-effectiveness of photodynamic diagnosis and urine biomarkers (FISH, ImmunoCyt, NMP22) and cytology for the detection and follow-up of BC. Health Technol Assess. 2010;14(4):1-331.

66. Guo A, Wang X, Gao L, Shi J, Sun C, Wan Z. Bladder tumour antigen (BTA stat) test compared to the urine cytology in the diagnosis of BC: A meta-analysis. Can Urol Assoc J. 2014;8:E347-52.

67. Aebersold R, Mann M. Mass-spectrometric exploration of proteome structure and function. Nature. 2016;537(7620):347-55.

68. Frantzi M, Vlahou A. Ten Years of Proteomics in BC: Progress and Future Directions. BC. 2017;3:1-18.

69. Zuiverloon TCM, de Jong FC, Theodorescu D. Clinical decision making in surveillance of non-muscle-invasive BC: the evolving roles of urinary cytology and molecular markers. oncology (Williston Park). 2017;31(12):855-62.

70. D'Costa JJ, Goldsmith JC, Wilson JS, Bryan RT, Ward DG. A systematic review of the diagnostic and prognostic value of urinary protein biomarkers in urothelial BC. Bladder Cancer. 2016;2:301-17.

71. Sathianathen NJ, Butaney M, Weight CJ, Kumar R, Konety BR. Urinary biomarkers in the evaluation of primary hematuria: a systematic review and meta-analysis. Bladder Cancer. 2018;4:353-63.

72. Schmitz-Drager BJ, Droller M, Lokeshwar VB, et al. Molecular markers for $\mathrm{BC}$ screening, early diagnosis, and surveillance: the WHO/ICUD Consensus. Urol Int. 2015;94(1):1-24.

73. Todenhofer T, Hennenlotter J, Kuhs U, et al. Influence of urinary tract instrumentation and inflammation on the performance of urine markers for the detection of BC. Urology. 2012;79:620-4.

74. Styrke J, Henriksson H, Ljungberg B, et al. Evaluation of the diagnostic accuracy of UBC((R)) Rapid in BC: a Swedish multicentre study. Scand J Urol. 2017;51(4):293-300. 
75. Huang YL, Chan J, Yan W, Zang D, Qin O, Deng AM. Diagnostic accuracy of cytokeratin-19 fragment (CYFRA 21-1) for BC: a systematic review and meta-analysis. Tumor Biol. 2015;36(5):3137-45.

76. Dudderidge T, Stockley J, Nabi G, et al. A Novel, non-invasive test enabling $\mathrm{BC}$ detection in urine sediment of patients presenting with haematuria-a prospective multicentre performance evaluation of ADXBLADDER. Eur Urol Oncol. 2020;3(1):42-6.

77. Snell KIE, Ward DG, Gordon NS, et al. Exploring the roles of urinary HAI-1, EpCAM \& EGFR in BC prognosis \& risk stratification. Oncotarget. 2018;9(38):25244-53.

78. Kamat AM, Li R, O’Donnell MA, et al. Predicting response to intravesical Bacillus Calmette-Guérin immunotherapy: are we there yet? A systematic review. Eur Urol. 2018;73(5):738-48.
79. Lotan Y, Svatek RS, Krabbe LM, Xylinas E, Klatte T, Shariat SF. Prospective external validation of a $\mathrm{BC}$ detection model. J Urol. 2014;192:1343-8.

80. Todenhofer T, Hennenlotter J, Esser M, et al. Combined application of cytology and molecular urine markers to improve the detection of urothelial carcinoma. Cancer Cytopathol. 2013;121(5):252-60.

81. Shimizu Y, Furuya H, Bryant Greenwood P, et al. A multiplex immunoassay for the non-invasive detection of BC. J Transl Med. 2016;14(1):1-9.

82. Frantzi M, van Kessel KE, Zwarthoff EC, et al. Development and validation of urine-based peptide biomarker panels for detecting $B C$ in a multi-center study. Clin Cancer Res. 2016;22:4077-86.

83. Benderska-Soder N, Hovanec J, Pesch B, et al. Toward noninvasive follow-up of low-risk BC -rationale and concept of the UroFollow trial. Urol Oncol. 2020. 